\title{
Risk management in Lattenbach: a case study from Austria
}

\author{
J. Hübl ${ }^{1} \&$ M. Moser ${ }^{2}$ \\ ${ }^{I}$ Department of Civil Engineering and Natural Hazards, \\ University of Natural Resources and Applied Life Sciences, Vienna, \\ Austria \\ ${ }^{2}$ Austrian Service for Torrent and Avalanche Control, \\ Regional Office Lungau, Austria
}

\begin{abstract}
The catchment area of Lattenbach in the District of Landeck, Tyrol, Austria is prone to debris flows. Large mass movements represent debris sources within the catchment. Debris flows, documented since 1907, pose a threat to buildings in the village of Pians. The construction of technical mitigation measures date back to 1908. Up to now, numerous check dams have been built. However, in the transit section of the channel, many of them are damaged or destroyed. Therefore, the former technical protection concept had to be reconsidered. A general risk management concept was conducted, including a detailed risk analysis. The risk analysis was based on a detailed analysis of former debris-flow events and field survey in order to collect input parameters for process analysis. Different scenarios were calculated, varying the input hydrograph, the volume of potential debris sources and the sediment concentration. The simulation results were used to derive intensity maps for the prone settlement area. In a subsequent step, an impact analysis resulted in the determination of areas bearing a lack of safety was carried out, and an appropriate map was generated. Risk management in the Lattenbach area was based on a protection concept that combines active and passive mitigation measures. Active measures include a temporary debris storage basin in the transit section to lower the peak discharge, and an improvement of the hydraulic transport capacity of the receiving stream to reduce backwater effects. Passive mitigation measures are based on an existing monitoring system, which was technically improved to an information system in order to provide information to local authorities if a debris flow will occur. Keywords: risk analysis, risk management, torrent control, debris flows.
\end{abstract}




\section{Introduction}

The catchment area of Lattenbach with a drainage basin of about $5.3 \mathrm{~km}^{2}$ is located westwards of Landeck, Tyrol, Austria, and discharges into the river Sanna at the village of Pians, fig. 1. Geologically, the catchment is divided into a northern part (Northern Limestone Alps) and a southern part (Crystalline Alps). Numerous mass movements of different types result from this geological situation leading to a considerable debris potential. Accordingly, a lot of debris flow events are recorded in the local chronicles. These documents date back to the year 1907. Severe events causing remarkable damage are reported from the years 1911, 1912, 1925, 1944, 1949, 1965, 1966, 1973 and 1998. Following the major events, structural mitigation measures were conducted along the channel. Since 1908, approximately 20 check dams were constructed to stabilize the channel bed and to consolidate the slopes. A lot of them, especially in the middle reach, are partially destroyed. Thus, high investments have to be made to maintain them. Consequently, since these investments are expenditures of the public sector, they have to fulfil the requirement of efficiency. Thus, detailed risk analyses have to be carried out. Within the INTERREG IIIB Project Catchrisk, the Institute of Mountain Risk Engineering got an order from the Austrian Torrent and Avalanche Control (Regional office Upper Inn-Valley) to develop a new protection concept based on a detailed risk assessment.

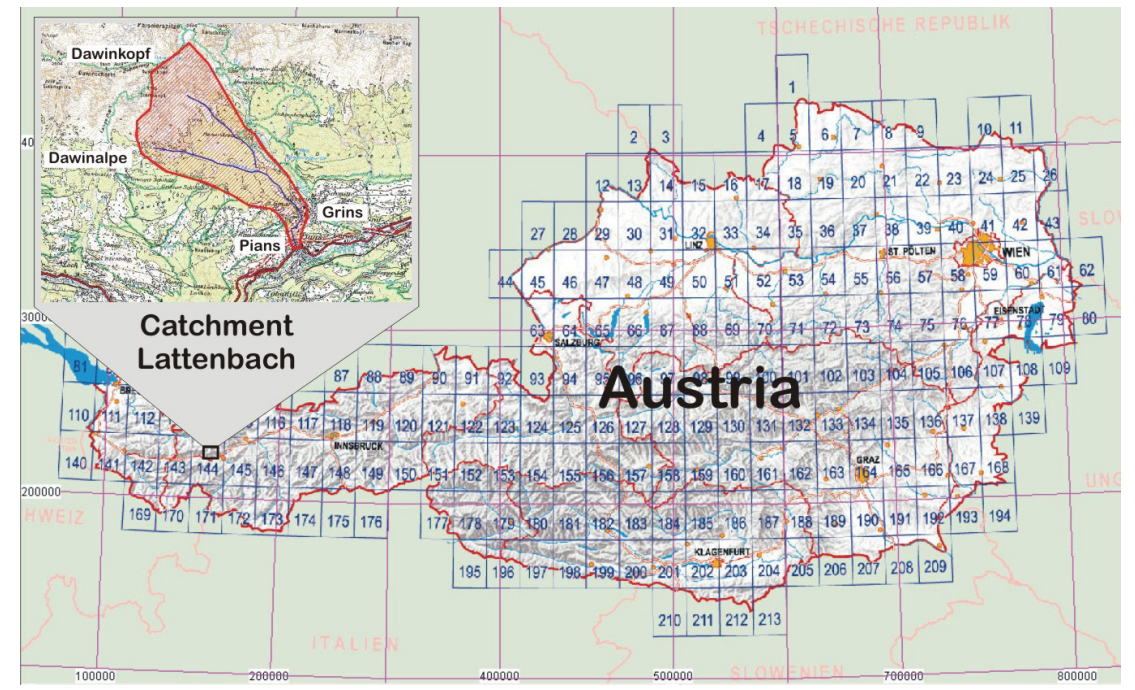

Figure 1: Location of the study area in Austria.

\section{Strategy of protection}

The strategy of protection is based on different tasks of risk analysis and risk management in order to find the most efficient combination of protection 
measures, fig. 2. Upon deducing objectives from risk analysis procedures, the protection concept outlines the strategy selected to reach the protection targets. The watershed was divided into different units according to specific hydraulic requirements. For every element of the watershed, individual management tasks were assigned. Those management tasks define the required performance of the elements with regard to the hazardous process. Applying this procedure, the sum of every single requirement must lead to the fulfilment of the overall protection objective [1].

A conceptual plan implying appropriate mitigation measures for the tasks derived from the above mentioned protection concept was developed. Thereby, the countermeasures have to ensure the most effective performance of the mitigation works.

In the next step, the modifications to the hazard resulting from the chosen combination of mitigation measures by means of risk analysis have to be verified. Additionally, the mitigation measures have to be evaluated regarding technical, ecological, societal and political constraints. The cost-effectiveness has to be examined by means of cost-benefit analyses.

The final step during the planning process comprised the detailed design of the mitigation measures and the work plan for all the projected constructions. Having established the mitigation measures in the catchment the utility of these measures had to be documented to allow for a better understanding of the interactions between the hazard process and the selected mitigation measures.

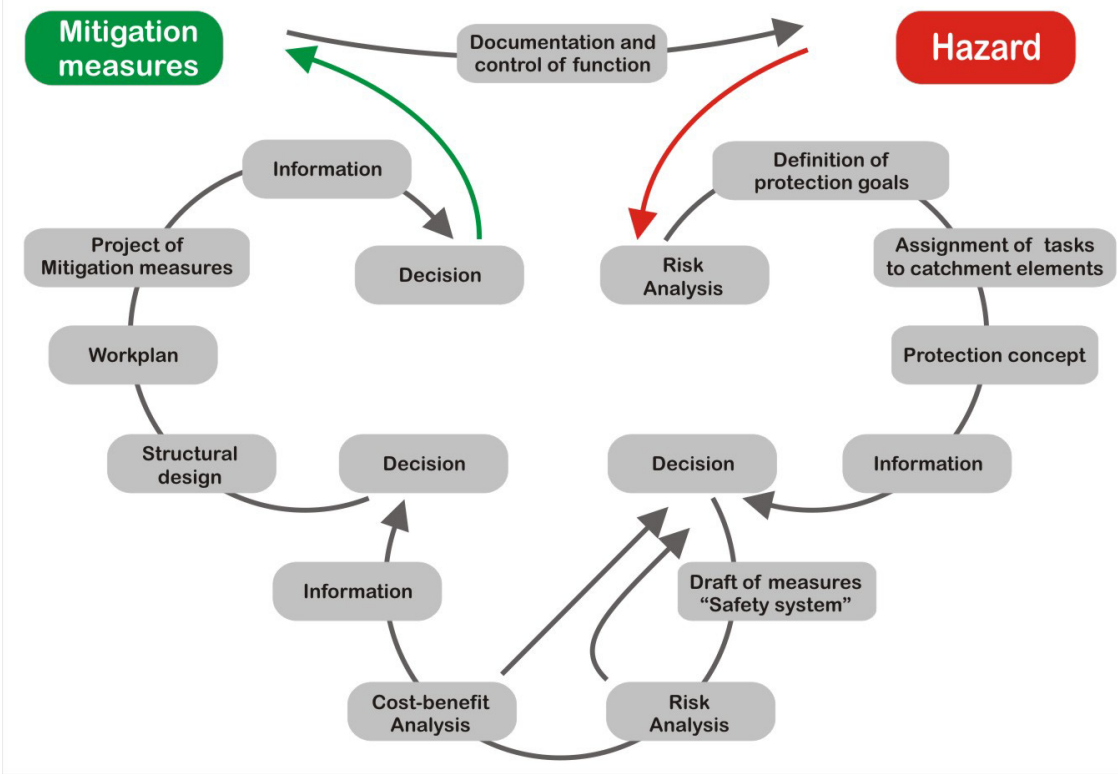

Figure 2: $\quad$ Strategy of protection [2]. 


\section{Risk analysis}

Risk analyses consist of a two-stage procedure, the analysis of the hazard itself and the analysis of the impact [3].

The hazard analysis is based on a detailed study of:

- former debris-flow events;

- meteorological and hydrological conditions triggering debris flows;

- a calculation of design hydrographs by means of hydrological simulation models;

- an analysis related to the effectiveness of existing mitigation measures;

- the debris potential for different scenarios;

- the estimation of rheological behaviour of different debris-water mixtures;

- a two-dimensional numerical simulation for the calculation of deposition patterns on the fan for different scenarios.

These hazard analyses resulted in process maps containing flow depths and velocities at the fan for different scenarios, fig. 3.

During the impact analysis, flow depths and velocities were classified into three categories of intensity by means of a matrix, which is based on empirical relationships. This classification was conducted for all calculated scenarios. Multiplying the intensity class of each cell with the spatial probability of occurrence and summing up these values lead through reclassification to a risk index map [4].

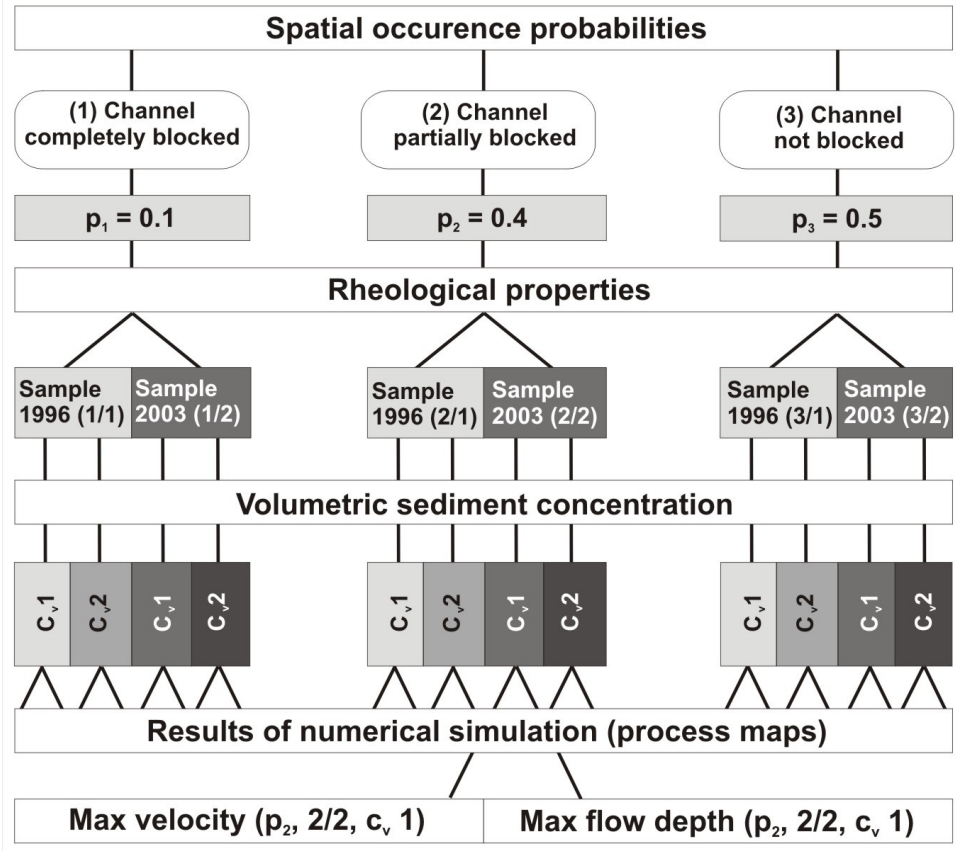

Figure 3: $\quad$ Schema of scenario's development. 
The indices from this risk index map were compared to the accepted vulnerability of individual objects on the fan (buildings, traffic routes). If the latter was higher than the calculated risk, a protection deficit resulted.

\subsection{Results of hazard analysis}

Analysing the chronicle of debris flows, the most probable trigger resulted from short-term thunderstorms. Applying the method of convective cells [5, 6], a precipitation height of $56 \mathrm{~mm}$ within 30 minutes had to be considered as a centennial event. Using different hydrological models, the hydrographs had shown a maximum peak discharge of 20 to $26 \mathrm{~m}^{3} / \mathrm{s}$ at the fan apex. These values were consistent with data derived form empirical formula applied in this region. The condition of the existing check dams along the channel was found to be unsound. Four of them were completely destroyed, 14 were heavily damaged by slope movements and thus were unreliable, and five of them were partly damaged. Only four check dams remained undamaged.

The geological situation is very complex due to a tectonic borderline. In the chronicle, deposited volumes of debris flows up to $10,000 \mathrm{~m}^{3}$ were reported on the fan. Several different landslides were spatially distributed in the catchment [7], many of them supplying directly the channel. The channel bed itself showed features of depth and lateral erosion. Two scenarios had been developed. The first scenario considered erosion and deposition if the existing technical mitigation measures would work properly. The second scenario included functional failures of the check dams, therefore, the estimated sediment yield of the scenarios scattered between $56,000 \mathrm{~m}^{3}$ and $63,600 \mathrm{~m}^{3}$.

Using process routing considerations debris flow was found to be the most probable design process in the catchment. Therefore, hydraulic calculations were applied. By means of additional rheological lab experiments (two scenarios) and a survey of the fan (three spatial scenarios), a two-dimensional simulation model had been applied, computing velocity and flow depths for all 12 scenarios, fig. 3 .

\subsection{Results of impact analysis}

For three spatial probabilities of occurrence at the fan (channel completely blocked, channel partly blocked, channel not blocked, see fig. 3, flow depths and velocities were ranked by a matrix into three degrees of intensity, see fig. 4 . For each calculated cell those degrees represented ranges of possible impact forces. Summing up the product of the maximum intensity value with the spatial probability for each cell, the risk index map was created. This map showed the most endangered areas of the fan. As presented in fig. 5, only small areas besides the channel were affected by debris flows.

The comparison of these indices with the vulnerability indices of the individual objects on the fan identified those areas that show a protection deficit. The most critical points were the bridges crossing the channel inside the village of Pians. They could be blocked by sediments and coarse woody debris leading to a retrograde in-channel deposition and continuative overtopping, depositing sediments on both sides of the channel. 

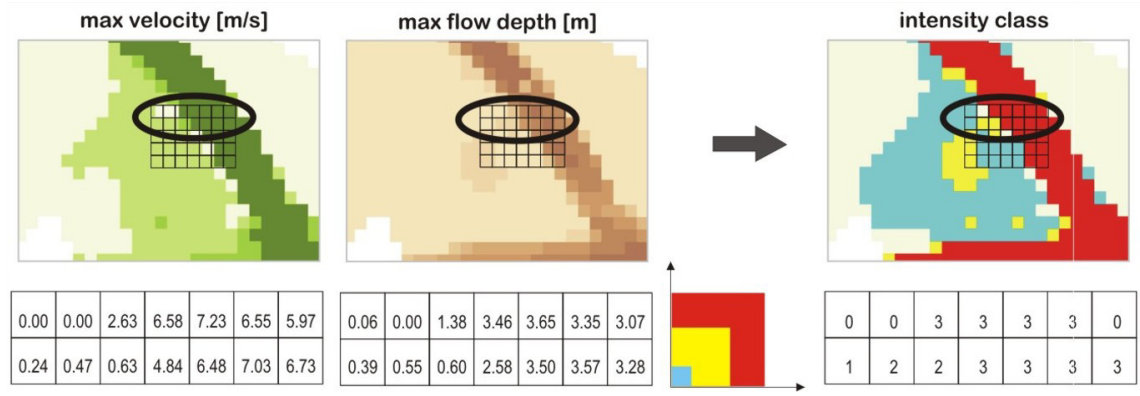

Figure 4: Derivation of intensity classes.



Figure 5: Risk index map of the Lattenbach fan. 
Additionally, the sediments of Lattenbach debris flows were found to probably cause tail water effects in the receiving stream Sanna, leading to inundation of the houses along this river.

In the middle reach an old stone bridge crosses the channel. This local situation had not been simulated, but due to local experience, the bridge could also be jammed.

\section{Risk management}

The calculated overall protection goals reached the predefined risk index " 0 " inside the village of Pians. They prevented people to stay on the bridges in the village and in the middle reach during a debris flow event. If due to technical and economical reasons a risk index of "0" could not be reached in the village, a risk index $<0.5$ should be achieved. Additionally, an early warning system was installed to protect the inhabitants.

The protection concepts included following tasks, fig. 6 :

hm 0: $\quad$ Confluence:

The receiving stream Sanna should be enabled to remove debris flow material without causing backwater effects.

hm 0-0.44: Channel within the village:

A debris flow peak discharge of $100 \mathrm{~m}^{3} / \mathrm{s}$ should pass the channel without overtopping.

hm 5.4-7.6: Natural channel with check dams:

The stabilising and consolidating effect of existing check dams must be guaranteed, erosion rate will not exceed $1 \mathrm{~m}^{3} / \mathrm{m}$.

hm 8.5-10.5: Natural channel:

Temporary sediment deposition of about $25,000 \mathrm{~m}^{3}$ to lower debris yield downstream. Debris floods with minor sediment yield should completely deposit their sediments in this reach.

hm 11.6-13.5: Natural channel with check dams:

The stabilising and consolidating effect of existing check dams must be guaranteed, erosion rate will not exceed $5 \mathrm{~m}^{3} / \mathrm{m}$. The potential of incorporating coarse woody debris into debris floods and debris flows must be minimised.

hm 13.5-20.0: Natural channel with check dams:

Due to the slight channel gradient no further incision of the channel will occur. The allowed lateral erosion rate is limited to $10 \mathrm{~m}^{3} / \mathrm{m}$.

hm 0.44, 1.25, 11.6: Bridges:

During a debris flow the bridges should be clear of people and traffic. Therefore the local authorities and/or the rescue organisations must be informed in sufficient time to block the bridges.

Within the safety system, following active and passive mitigation measures were suggested, see fig. 6 : 


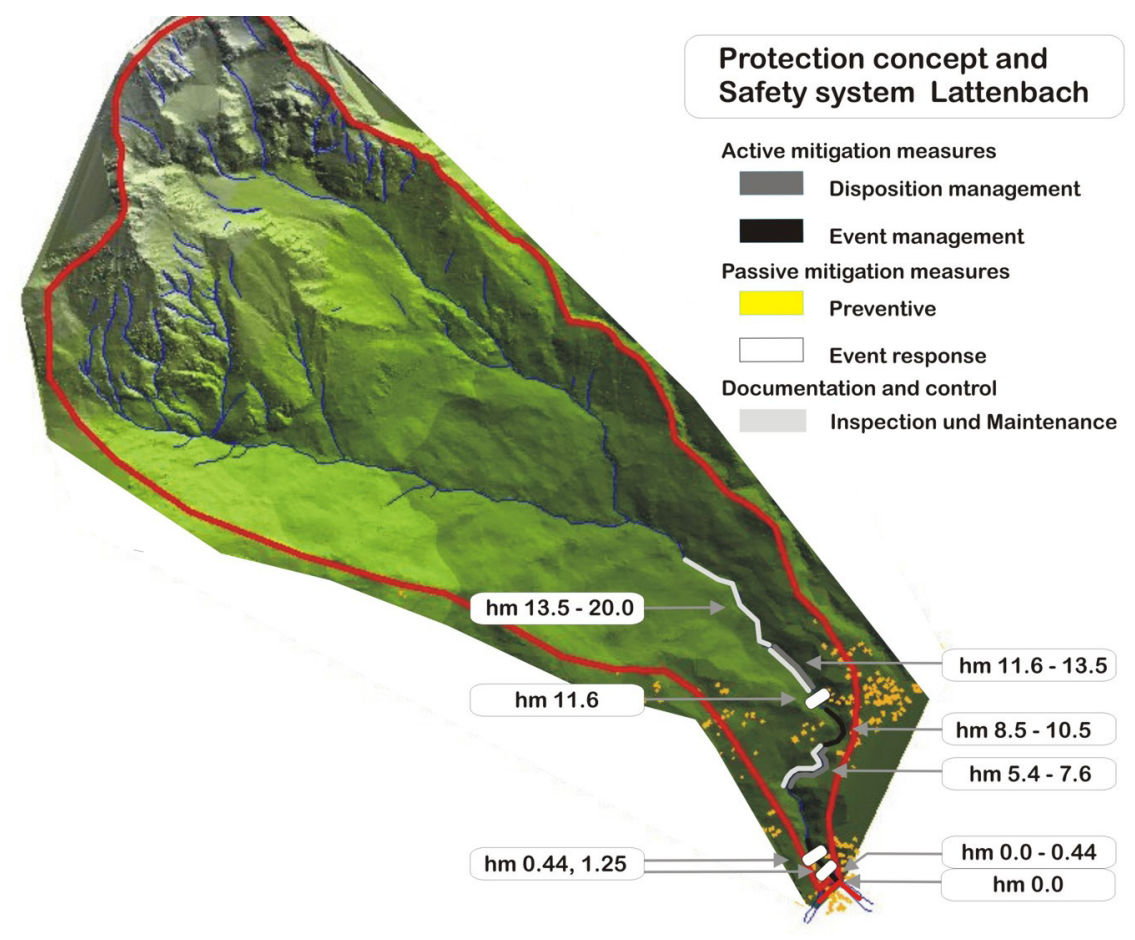

Figure 6: Protection concept and Safety system Lattenbach.

hm 0: $\quad$ Confluence:

The confluence of Lattenbach with the river Sanna had to be hydraulically optimised. This could be achieved by groynes on the right bank of Sanna combined with an extension of the right sided embankment of Lattenbach. Physical modelling was recommended before starting construction work.

hm 0-0.44: Channel within the village:

Heightening of double-sided masonry walls along the channel to improve channel capacity.

hm 5.4-7.6: Natural channel with check dams:

One visual inspection per year and maintenance of the check dam crests.

hm 8.5-10.5: Natural channel:

To enhance natural sediment deposition in this reach, structural mitigation measures could be implemented. Open dams such as slit- or sectional dams with a height of 5 meters will make a deposition of $25,000 \mathrm{~m}^{3}$ of sediments possible. In addition, coarse woody debris would detained to be transported downstream.

hm 11.6-13.5: Natural channel with check dams: 
One visual inspection per year and maintenance of the check dams. Frequent flowing avalanches deposit coarse woody debris in this section. The removal of this material is necessary.

hm 13.5-20.0: Natural channel with check dams:

No further maintenance of damaged check dams. Visual inspection of this reach and mechanical clearance if necessary.

hm 0.44, 1.25, 11.6: Bridges:

Technical improvement of the already existing monitoring system to enable the master station to distribute SMS via GSM to local authorities and rescue organisations. Additionally, the system should operate traffic lights on both sides of the bridges to govern the traffic.

This combination of different measures lead to the fulfilment of the protection aims postulated above. However, the results were deduced using a modelling approach, thus, the future behaviour of the catchment might differ from the modelled findings. There may be a change concerning the hydrological conditions (climate change) or the slope stability. If so, the safety system has to be adopted.

In Austria no procedure to evaluate protection of human lives is accredited by the official authorities, even if concepts related to natural hazards are available $[8,9]$. Thus, for the risk management in the Lattenbach area, a cost-benefit analysis could only be carried out in terms of direct damage to tangible assets. In consequence, an underestimation of benefits due to passive mitigation such as early warning systems results.

\section{Conclusion}

Until now, mainly structural mitigation measures are used for risk mitigation measures. Several directives allow the engineers to design adequate structural works. However, these structures have to be maintained and therefore they are cost-intensive. Thus, passive mitigation measures such as early warning systems might complement or - if justifiable - replace structural works. Nevertheless, no regulations exist for such systems. Therefore, it is necessary to define (legal) regulations and administrative as well as actuarial frameworks.

\section{References}

[1] Hübl, J., Fiebiger, G., Debris-flow mitigation measures (Chapter 18). Debris-flow Hazards and Related Phenomena, ed. Jakob, M. \& Hungr, O., Springer-Verlag: Berlin, Heidelberg, New York, ISBN 3-540-20726-0, pp. 445-487, 2005

[2] Hübl, J., Moser, M., Risikomanagement Lattenbach: Generelle Planung von Schutzmaßnahmen, IAN Report, 95 (2), Institut für Alpine Naturgefahren, Universität für Bodenkultur Wien, (unpublished), 2004 
[3] Bundesamt für Umwelt, Wald und Landschaft (BUWAL), Risikoanalysen bei gravitativen Naturgefahren - Methoden, Umwelt-Materialien, 107/I, BUWAL, Bern, 1999

[4] Hübl, J., Moser, M., Risikomanagement Lattenbach: Risikoanalyse, IAN Report, 95 (1), Institut für Alpine Naturgefahren, Universität für Bodenkultur Wien, (unpublished), 2004

[5] Lorenz, P., Skoda.,G., Bemessungsniederschläge kurzer Dauerstufen $(\mathrm{D}<=12)$ mit inadäquaten Daten. Mitteilungsblatt des Hydrographischen Dienstes in Österreich, 80, Wien, 2000

[6] Lorenz, P., Skoda.,G., Bemessungsniederschläge kurzer Dauerstufen $(\mathrm{D}<=12)$ mit inadäquaten Daten. Mitteilungsblatt des Hydrographischen Dienstes in Österreich, 80, Wien, 2000

[7] Wieser, R., Die geologischen Verhältnisse am Südrand der Lechtaler Alpen zwischen Stanz und der Dawinalm unter besonderer Berücksichtigung der Massenbewegungen, Ergänzungen zum Vorbericht der Diplomarbeit, Universität Innsbruck (unpublished), 1998

[8] Fuchs, S., McAlpin, M.C., The net benefit of public expenditures on avalanche defence structures in the municipality of Davos, Switzerland. Natural Hazards and Earth System Sciences, 5, pp. 319-330 2005

[9] Wilhelm C., Wirtschaftlichkeit im Lawinenschutz, Mitteilungen Eidgen. Insitut für Schnee- und Lawinenforschung, 54, Davos, 1997 